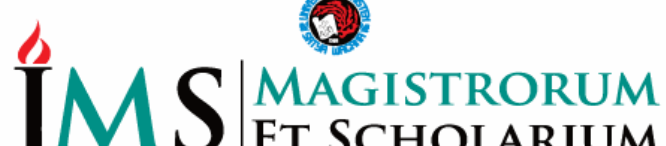

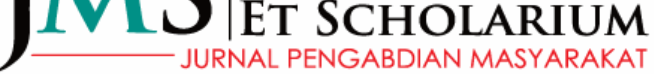

P-ISSN: 2722-9270 ejournal.uksw.edu/jms

\section{Pengenalan Dan Pelatihan Pemrograman Berbasis Blok Bagi Anak}

Erba Lutfina

Anindya Khrisna Wardhani

Universitas Nasional Karangturi; erbalutfiana@gmail.com.

A R T I C L E I N F O

Article history:

Received 12-07-2020

Revised 30-07-2020

Accepted 25-08-2020

JEL Classification:

Key words:

Pemrograman, coding, game, pemrograman berbasis blok

DOI:

\section{A B S T R A C T}

The introduction of programming knowledge for elementary and middle school students is needed to improve children's thinking and creativity. As educators who pay attention to programmingbased education, lecturers of the Karangturi National University provide training on programming or coding for educators and general public. This comunity service aims to provide insight to parents, educators, and children about programming as well as skills that are needed to create digital applications. This community service activity was carried out in 2 sessions, the introduction of coding applications for children such as scratch, code.org, CodeCombat, Appinventor, and the training on the use of these applications for participants. The training material includes the explanations of benefits of various applications, the differences implementation of those applications and the evaluation of the applications by participants. Throught the community service, it is expected that participants can understand the basic skill of programming and able to deliver and taught the material to children.

\section{A B S T R A K}

Pengenalan pengetahuan pemrograman bagi siswa sekolah dasar dan menengah sangat diperlukan untuk meningkatkan cara berpikir dan kreatifitas anak-anak. Oleh karena itu, dosen Program Studi Sistem Informasi Universitas Nasional Karangturi selaku tenaga pendidik yang menaruh perhatian pada pendidikan berbasis pemrograman memberikan pelatihan mengenai pemrograman atau coding bagi tenaga pendidik maupun masyarakat umum. Pengabdian ini memiliki tujuan untuk memberikan wawasan kepada orang tua, pendidik maupun anak megenai pemrograman atau coding serta kriteria atau keterampilan apa saja yang diperlukan untuk membuat suatu produk aplikasi digital. Kegiatan pengabdian masyarakat ini dilaksanakan dalam 2 sesi yaitu penyampaian mengenai pengenalan aplikasi coding untuk anak seperti scratch, code.org, codecombat, appinventor dan pelatihan penggunaan aplikasi tersebut bagi peserta. Materi pelatihan meliputi penjelasan 
manfaat, perbedaan berbagai aplikasi yang digunakan, tahapan penggunaan aplikasi, sampai dengan evaluasi penggunaan aplikasi oleh peserta. Diharapkan dari kegiatan pengabdian masyarakat ini, peserta dapat memahami yang kemudian dapat disampaikan dan diajarkan ke anak-anak.

\section{PENDAHULUAN}

Saat ini terdapat berbagai pengakuan yang berkembang bahwa pemrograman merupakan keterampilan yang penting bagi siswa agar dapat berpartisipasi penuh dalam dunia teknologi digital (Weintrop \& Wilensky, 2017). Menanggapi kebutuhan ini, berbagai gagasan baru sedang dilakukan untuk mengembangkan pengetahuan di bidang ilmu komputer kepada para siswa sekolah dasar maupun menengah(Flannery et al., 2013).

Aktivitas mengembangkan pengetahuan pemrograman pada siswa telah menghasilkan kurikulum baru yaitu pengenalan materi pemrograman bagi siswa sekolah dasar dan menengah. Banyaknya tools yang digunakan dalam pengenalan pemrograman cenderung berfokus pada keterampilan akademik dasar, seperti pengenalan huruf dan angka dari pada ketrampilan berpikir tingkat tinggi dan kreatif (Sullivan, Ave, Elkin, Ave, \& Ave, 2015). Hal ini mengacu pada asumsi bahwa bahwa anak-anak berumur 5 sampai 8 tahun dapat belajar dan menerapkan konsep pemrograman dan pemecahan masalah untuk membuat animasi dan cerita interaktif (Amber \& Wagner, 2012). Oleh karena itu, dibutuhkan teknologi pengajaran yang kuat dan dukungan pembelajaran yang disesuaikan untuk anak usia dini. Desain teknis pembelajaran harus disesuaikan dengan perkembangan sosial, emosional, fisik, dan kognitif anak (Hu, Zekelman, Horn, \& Judd, 2015).

Banyak dari kurikulum pemrograman bagi siswa sekolah dasar dan menengah menggunakan pengenalan komputasi pemrograman berbasis blok yang berfungsi sebagai pengantar awal siswa untuk melakukan praktek pemrograman (Milne, 2017). Contohnya, terdapat berbagai kurikulum pemrograman yang diterapkan sebagai kegiatan ekstrakulikuler pada siswa sekolah dasar dan menengah. Sumber materi dan metode pengejaran dikelas dapat diperoleh dari berbagai sumber. Contohya Code.org yang menyediakan materi pembelajaran dengan menggabungkan penggunaan berbagai tools pemrograman berbasis blok (Hasan et al., 2017).

Berdasarkan latar belakang tersebut, Program Studi Sistem Informasi Universitas Nasional Karangturi menyelenggarakan kegiatan pelatihan dan sosialisasi bagi masyarakat umum maupun tenaga pendidik untuk memperkenalkan dan mengajak anak belajar coding. Pelatihan ini dirancang sebagai kegiatan pengabdian kepada masyarakat, sebagai salah satu upaya meningkatkan kualitas sumber daya manusia dengan memberikan pemahaman tentang pemrograman pada komputer atau coding. Dengan pemahaman ini, peserta akan dapat mengembangkan diri dengan mempelajari dan menerapkan coding untuk berpartisipasi pada perkembangan teknologi.

Target kegiatan pengabdian masyarakat ini antara lain memberikan wawasan kepada peserta mengenai pemrograman atau coding, platform apa saja yang dapat digunakan untuk belajar coding, serta kriteria atau keterampilan apa saja yang diperlukan untuk membuat suatu produk aplikasi digital. Dengan demikian, peserta 
bisa mengajarkan dan mulai menekuni pemrograman coding sehingga dapat menghasilkan produk aplikasi yang bermanfaat.

\section{METODE PELAKSANAAN}

Metode kegiatan pengabdian kepada masyarakat ini dilakuan secara daring (online) dengan menggunakan aplikasi Zoom dan disiarkan secara langsung melalui platform Youtube pada tanggal 23 Juni 2020 di Universitas Nasional Karangturi. Peserta kegiatan ini diikuti oleh 127 peserta yang terdiri dari orang tua siswa, dosen, mahasiswa, guru Sekolah Dasar dan Menengah, bahkan siswa Sekolah Dasar dan Menengah. Pendekatan yang digunakan oleh tim pengabdian adalah dengan menganalisis dan merancang apa saja kebutuhan yang diperlukan dalam pelatihan (Babu, Bharathi, Pradesh, \& Pradesh, 2013). Setelah itu mengembangkan materi pelatihan yang dibutuhkan, dilanjutkan dengan pelaksanaan pelatihan serta evaluasi kegiatan pelatihan sesuai dengan model pelatihan yang diusulkan oleh Goad (1982:11).

Kemudian untuk metode kegiatan yang digunakan dalam pengabdian ini adalah demonstrasi dan pelatihan mengenai pembuatan aplikasi digital dengan menggunakan coding dan mengetahui apa saja platform yang dapat digunakan untuk belajar coding. Penjelasan kegunaan dan fitur yang ditampilkan di screen webinar. Kemudian dilanjutkan dengan penjelasan langkah-langkah penggunaan aplikasi coding untuk anak yang dibantu oleh tim pengabdian untuk membantu peserta yang mengalami kesulitan.

Penyelenggara kegiatan pengabdian ini adalah Fakultas Sains dan Teknologi Universitas Nasional Karangturi Semarang. Instruktur pelatihan merupakan dosen program studi Sistem Informasi yang memaparkan materi mengenai sistem yang digunakan.

\section{HASIL DAN PEMBAHASAN}

Kegiatan pengabdian masyarakat ini dilaksanakan dalam 2 sesi yaitu penyampaian mengenai pengenalan aplikasi coding untuk anak seperti scratch, code.org, codecombat, appinventor dengan durasi 20 menit dan pelatihan penggunaan aplikasi tersebut bagi peserta dengan durasi selama 60 menit. Pada sesi pertama, instruktur memberikan pemaparan mengenai manfaat aplikasi coding berbasis game kepada peserta. Materi yang disampaikan berisi kegunaan, konsep dan fitur-fitur yang terkait dengan aplikasi coding untuk anak-anak. Pada materi pertama ini peserta dikenalkan secara lebih dalam tentang konsep aplikasi coding menggunakan block programming sebagai alat bantu anak membuat aplikasi game edukasi. Dari paparan materi yang diberikan, peserta aktif mengajukan pertanyaan untuk lebih memahami konsep aplikasi yang disampaikan dan memberikan saran terhadap aplikasi coding yang kemudian dapat disampaikan dan diajarkan ke anakanak oleh para orangtua atau orang dewasa. 


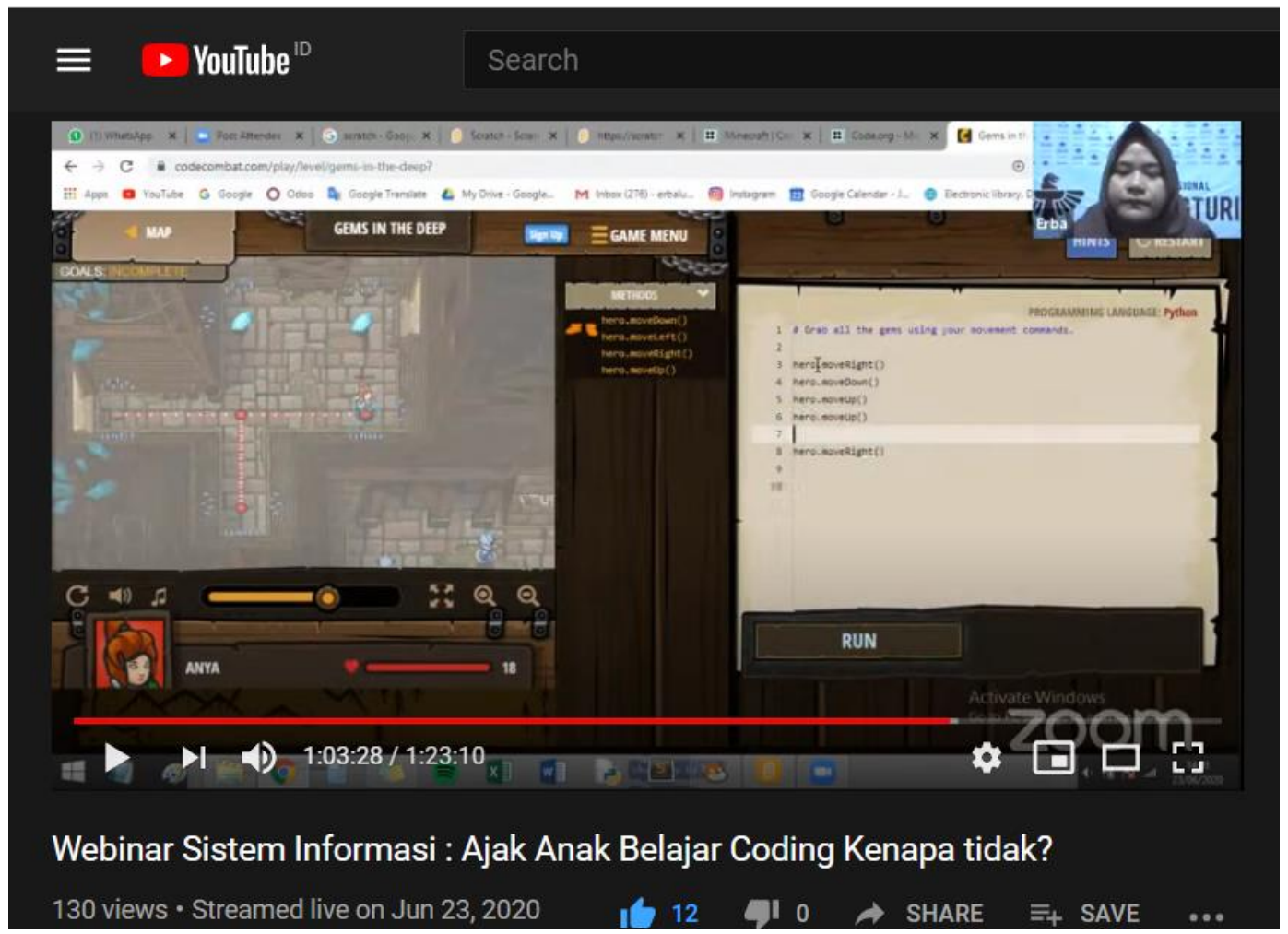

Gambar 1. Pemaparan Materi Coding untuk Anak

Selanjutnya pada sesi kedua, peserta diberikan langkah-langkah penggunaan aplikasi scratch, code.org, codecombat, appinventor dari mulai login sampai penggunaan fitur-fitur yang ada dalam berbagai aplikasi tersebut. Pada sesi ini tim pengabdian membantu peserta yang mengalami kesulitan dalam menggunakan aplikasi yang dipaparkan. Peserta secara aktif memberikan masukan dan berdiskusi dengan instrukur mengenai penggunaan fitur dan output dari aplikasi yang digunakan. Pada bagian akhir sesi dilakukan kegiatan tanya jawab dan penyampaian feedback dari peserta. Dari tahap tersebut diketahui bahwa setiap peserta berhasil mengakses dan menjalankan fitur-fitur yang ada pada aplikasi scratch, code.org, codecombat, appinventor.

\section{SIMPULAN}

Dari kegiatan pengabdian masyarakat pelatihan coding bagi anak didapatkan hasil bahwa kegiatan pengabdian relevan dan sesuai dengan kebutuhan para peserta yaitu orang tua dan anak-anak. Hal tersebut terlihat dari antusias peserta dalam mengikuti setiap sesi kegiatan dengan aktif bertanya dan memberikan feedback dari pemaparan materi yang diberikan dengan mengisi form tanggapan dari kegiatan yang dilaksanakan. Dari pelaksanaan kegiatan juga didapatkan bahwa sebanyak 119 peserta sangat memahami dan dapat mengakses semua fitur aplikasi coding, sedangkan sebanyak 8 peserta mengalami kesulitan dalam menjalankan aplikasi app inventor dikarenakan tingkat kesulitan yang tinggi dan masalah koneksi atau gadget yang digunakan tidak mendukung aplikasi app inventor. 
Tindak lanjut kegiatan pengabdian masyarakat dapat dilakukan sesuai dengan feedback yang diberikan dari peserta dan dapat dilakukan sesuai dengan kebutuhan tiap peserta karena adanya perbedaan usia dan pemahaman bagi anak-anak pengguna aplikasi coding, serta setiap aplikasi memiliki tingkat kesulitan yang berbeda-beda.

\section{DAFTAR PUSTAKA}

Amber, A., \& Wagner, K. (2012). Programming by Voice : A Hands-Free Approach for Motorically Challenged Children.

Babu, P. C., Bharathi, K. C. K., Pradesh, A., \& Pradesh, A. (2013). Assessment of maintainability factor. International Journal of Computer Science Engineering and Information Technology Research, 3(3), 29-42.

Flannery, L. P., Ave, C., Kazakoff, E. R., Ave, C., Silverman, B., Bers, M. U., ... Resnick, M. (2013). Designing ScratchJr : Support for Early Childhood Learning Through Computer Programming, 1-10.

Hasan, M. A., Nasution, N., Setiawan, D., Studi, P., Informatika, T., Ilmu, F., ... Inventor, A. (2017). Game Bola Tangkis Berbasis Android Menggunakan App Inventor, $x(\mathrm{x}), 160-169$.

Hu, F., Zekelman, A., Horn, M., \& Judd, F. (2015). Strawbies : Explorations in Tangible Programming, 1-4.

Milne, L. R. (2017). Blocks4All: making block programming languages accessible for blind children. ACM SIGACCESS Accessibility and Computing, (117), 2629.

Sullivan, A., Ave, C., Elkin, M., Ave, C., \& Ave, C. (2015). KIBO Robot Demo : Engaging Young Children in Programming and Engineering.

Weintrop, D., \& Wilensky, U. R. I. (2017). Comparing Block-Based and Text-Based Programming in High School Computer Science Classrooms, 18(1), 1-25. 